\title{
Working
}

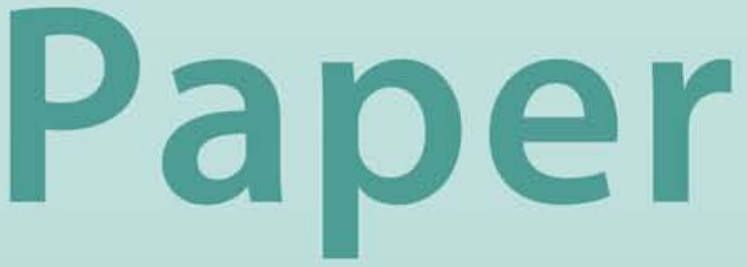




\section{Monetary Policy and the Central Bank in Jordan}

Samar Maziad 
IMF Working Paper

Strategy, Policy, and Review Department

Prepared by Samar Maziad ${ }^{1}$

Authorized for distribution by Christian Mumssen

August 2009

\begin{abstract}
This Working Paper should not be reported as representing the views of the IMF.

The views expressed in this are those of the author(s) and do not necessarily represent those of the IMF or IMF policy. Working papers describe research in progress by the author(s) and are published to elicit comments and to further debate.

The Central Bank of Jordan (CBJ) and its operational independence changed over time in line with the evolution of the monetary policy framework and as a result of the currency crisis in the late 1980s. The paper examines the developments of the CBJ, its independence in conducting monetary policy and the various instruments at its disposal, with special focus on the certificates of deposit (CDs) market, the main monetary policy instrument, and the treasury bill market. The paper also examines the issue of the autonomy of monetary policy in Jordan given the influence of world interest rates. Although, Jordan operates an exchange rate peg, which has been fixed to the USD since 1995, there is some room for flexibility in operating monetary policy in the short-run, where the CBJ has some autonomy in determining the spread between domestic and US interest rates. VAR and VECM results suggest that the response of the policy rate in Jordan to innovations in the US Federal Fund's rate is less than one-for-one. In the short-run, the CBJ appears to conduct monetary policy in response to domestic inflation and a measure of the domestic output gap.
\end{abstract}

JEL Classification Numbers: E4, E52, E58, O23

Keywords: Jordan, Monetary policy, Central bank independence

Author’s E-Mail Address: smaziad@imf.org

\footnotetext{
${ }^{1}$ The author would like to thank Messrs Husain, Almounsor, and Ms. Ter-Martirosyan for their valuable comments. The author also appreciates the discussion and insights of the participants at the $10^{\text {th. }}$ Mediterranean Research Meeting of the Robert Schuman Center for Advanced Studies, European University Institute, held in March 2009, where an earlier draft of this paper was presented.
} 


\section{Table of Contents}

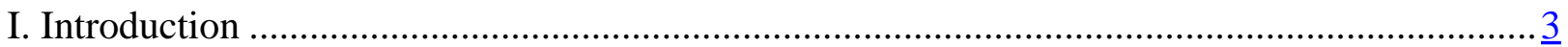

II. The Monetary framework and the impact of the currency crisis ...................................... 4

III. CBJ independence and monetary policy .............................................................. 1

IV. Monetary policy instruments and operations........................................................... 13

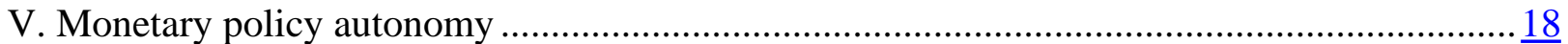

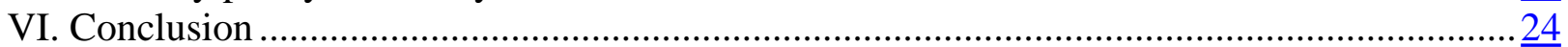

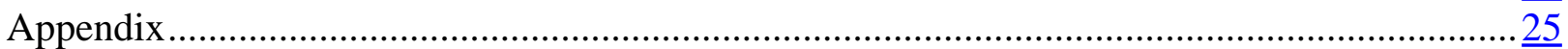

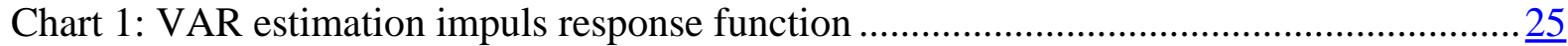

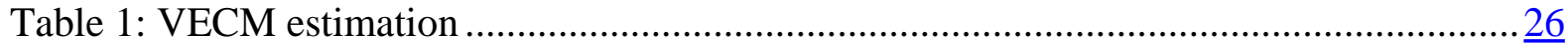

Table 2: VECM variance decomposition of policy rate in Jordan...................................... 27 


\section{INTRODUCTION}

Jordan is a small open economy with a limited industrial base and relies heavily on foreign aid and workers' remittances for foreign currency resources. In the 1970s, Jordan witnessed high growth and large capital inflows due to the boom in oil prices, which contributed to increased foreign revenues through the large flow of aid and workers' remittances from the Gulf States. With the drop in oil prices in the early 1980s, the main sources of foreign exchange flows, aid and remittances, dried up, resulting in economic recession and stagnation throughout the decade. Jordan resorted to heavy external borrowing to compensate for the fall in foreign currency and public revenues more generally. The accumulation of foreign debt coupled with expansionary fiscal policy and accommodating monetary policy culminated in an exchange rate crisis in 1989-90 and a sharp devaluation of the fixed exchange rate. In the aftermath of the crisis, Jordan pursued macroeconomic stabilization successfully, and has maintained prudent policies since, and restored exchange rate stability, supported by a marked development in the monetary policy framework, including monetary policy instruments and enhanced central bank independence.

The paper will discuss the evolution of the monetary framework in Jordan, including the exchange rate regime, the conduct of monetary policy and the evolution of central bank independence, with reference to the impact of the currency crisis on the evolution of the monetary framework. ${ }^{2}$

The paper will also discuss the question of monetary policy independence in the context of Jordan's exchange rate peg to the USD. Empirical research has shown that floating exchange rate regimes do not necessarily allow a country to operate an independent monetary policy given the strong influence of world interest rates. Similarly, countries operating a fixed exchange rate regime may have some flexibility in designing monetary policy, at least in the short run. The hypothesis of monetary policy independence will be tested in the case of

\footnotetext{
${ }^{2}$ There is little published research on central banking in Jordan; this paper thus draws heavily on publications of the Central Bank of Jordan (CBJ), publicly accessible IMF reports, a series of interviews conducted with central bank and government officials in June 2004, and the return to a questionnaire administered to the CBJ officials. The discussion of the central bank law relies on the 1971 CBJ law and its amendments in 1989 and 1992. All data is obtained from IFS or the CBJ unless otherwise indicated.
} 
Jordan using VAR/VECM analysis to study the influence of USD interest rates on monetary policy. The results show that, along with adjusting monetary policy in response to USD interest rate movement, the CBJ is also able to respond to domestic inflation and the output gap. There is some room for flexibility in operating monetary policy in the short run, where the CBJ has some autonomy in determining the spread between domestic and US interest rates. The results suggest that the response of the policy rate in Jordan to innovations in the US Federal Fund's rate is less than one-for-one. In the short-run, the CBJ appears to conduct monetary policy in response to domestic inflation and a measure of the domestic output gap.

The paper is organized as follows: section II describes the monetary framework prior to the currency crisis in 1989/90; section III discusses the evolution of central bank independence; section IV describes monetary policy instruments and operations; section V presents the results of the empirical analysis on monetary policy autonomy; and section VI concludes.

\section{THE MONETARY FRAMEWORK AND THE IMPACT OF THE CURRENCY CRISIS}

The CBJ was established in 1964 with little legal or statutory independence. Over time the degree of actual autonomy has increased substantially, mainly during the 1990s after the severe balance of payments crisis that saw the fixed exchange rate devalued by more than 100 percent. The pre-crisis monetary framework relied on a fixed exchange rate with a parity that was pegged to the pound sterling as part of the colonial legacy but was officially abandoned with the devaluation of the sterling in 1967, to be replaced by a peg directly to the USD. In 1975, the authorities abandoned the USD peg with the breakdown of the Bretton Woods system and pegged the JD to the SDR instead with a band of +/- 2.25 percent to avoid excessive fluctuations that might result from pegging to the USD alone (CBJ, 1989).

Until the early 1980s, Jordan enjoyed large inflows of capital in the form of aid and worker remittances, which supported the fixed exchange rate regime. Foreign grants amounted to 54 percent of revenues in 1975 and until 1983 averaged 42 percent of total government revenues, while remittances amounted to almost 47 percent of GDP in 1979 and averaged 22 percent of GDP annually until 1983. With the fall in world oil prices and the decline in production from Gulf States in the early 1980s, the flow of foreign capital almost came to a 
halt. Foreign grants were halved from their peak of JD 210 million in 1979 to JD 106 million in 1984, while remittances decreased sharply from JD 456 million (47 percent of GDP) in 1979 to JD 310 million (16 percent of GDP) in 1985.

To overcome this shortfall, the authorities resorted to heavy external borrowing. Foreign debt increased by an annual average of 17 percent from 1983 to 1987, reaching a peak of 164 percent of GDP in 1988. If domestic debt was also included, total government debt would amount to a staggering 203 percent of GDP. With the large build-up of foreign debt, interest payments increased steadily from less than 2 percent of GDP in1983 to almost 11 percent of GDP during 1990-91. This sharp increase also reflected the strong depreciation of the currency in 1988-89 (IMF, 1995, p. 28).

Jordan witnessed declining growth rates during the 1980s. Real GDP had been growing strong from 1976 until 1982 at 13 percent on average, before it declined to 1.5 percent in 1988, with a sharp contraction (-10 percent) in 1989 as a result of the crisis. The inflation rate was moderate and averaged 6 percent during the 1980s (See summary table 1 in the next section).

Monetary conditions were generally accommodating throughout the 1980s with broad money growth averaging 13 percent and domestic credit growing at 20 percent annually. Monetary policy from the mid-1970s into the late 1980s was largely passive and the CBJ had only a few instruments and limited ability to influence monetary conditions. Until 1990, the CBJ had only direct control instruments at its disposal to influence liquidity and credit conditions; including reserve requirements, liquidity ratios and interest rate ceilings. These instruments were adjusted frequently to support bank liquidity and encourage credit expansion, as monetary policy was geared towards supporting the overall government policy of stimulating the economy (IMF, 1995).

Jordan's dependence on foreign capital, expansionary fiscal policy, and the large built-up of foreign debt, led to the currency crisis that was inevitable by the end of the decade, as public debt reached unsustainable levels. 
The first signs of the crisis appeared in mid-1986 when the exchange rate of the JD exceeded the official 2.25 percent $^{3}$ fluctuation band around the SDR, and a parallel foreign exchange market appeared. The margin between the official and parallel market rates increased rapidly to 200 -fold in 1988 , as the parallel market premium reached 20 piastres from 0.2 when the parallel market first appeared (interview with CBJ, 2004). ${ }^{4}$

The continued pressures on the currency resulted in a significant loss of reserves, as foreign reserves declined from almost JD 425 million in 1987 to JD 110 million in 1988, or a decrease of almost 75 percent; gold reserves declined by over 30 percent over the course of the same year, and arrears in debt service started to appear by the end of 1988 (Kanakria, 2002). In April 1988, the CBJ suspended currency sales, but the pressures continued and forced a devaluation of 5 percent by June of the same year. At the same time, the government introduced some measures to limit currency transfers abroad. ${ }^{5}$

The currency crisis resulted in the devaluation of the exchange rate (measured against SDRs) by 65 percent in 1988 and an additional 33 percent in 1989, whereby the JD was re-pegged at JD 0.94/SDR in 1990, representing a devaluation of 140 percent from its rate of JD 0.39/SDR before the crisis.

The Jordanian authorities recognize that heavy government borrowing to finance current expenditure, and the associated debt service, led to the exchange rate crisis in 1988-89. The ministry of finance also acknowledged that one of the main reasons behind the crisis was

\footnotetext{
${ }^{3}$ IFS data shows that the JD remained stable against SDR but it depreciated by 4 percent against the USD in April 1986.

${ }^{4}$ Along with the emerging currency crisis, a major trade crisis also erupted in 1988 with the country's largest trading partner, Iraq. In 1983, the Economic Security Committee (ESC) introduced a policy of providing letters of credit to the Iraqi government to finance imports from Jordan to the tune of USD 100 million annually on average. In 1988, corruption and lack of oversight resulted in Iraqi importers overspending their credit by USD 240 million, which resulted in overall Iraqi debt to Jordan rising to almost USD 600 million. The credit scandal caused the government to freeze all letters of credit in order to investigate the legitimacy of the claims of Jordanian traders (Carroll, 2003, Satloff, 1992). The crisis dealt an additional blow to Jordan's fragile external position and contributed to the already growing speculation against the currency.

${ }^{5}$ Severe pressures on the currency erupted when King Hussein announced in July that Jordan would disengage from the West Bank, which led Palestinians to panic and dump large holdings of JD, especially in the West Bank. Amid this confusion, the CBJ refused to provide foreign currency to the private sector and in February 1989, the government began officially to devalue the JD and announced that it was floating the currency for a brief period before embarking on a stabilisation programme (Satloff, 1992).
} 
"borrowing from the Central Bank” (Hammour, 2005, p.5) ${ }^{6}$. In the post-crisis period, fiscal discipline and the enforcement of limitation on central bank financing of the budget deficit were critical reforms in the environment, in which the CBJ operated and contributed to increasing its actual independence and effectiveness in operating monetary policy. Similar views were also expressed by Kanakria (2002) and Hammour (2006). Thus the reform efforts that followed would have enjoyed the support of both the government and the CBJ. This facilitated the evolution of a more sophisticated monetary framework, including greater independence for the central bank, supported by increased fiscal discipline.

\section{CBJ INDEPENDENCE AND MONETARY POLICY}

Like many central banks in the MENA region and elsewhere, the CBJ was established with little autonomy, particularly in terms of political independence. ${ }^{7}$ However the CBJ's degree of independence, especially economic or instrument independence, increased noticeably since the early 1990s. This development both impacted and was influenced by the increased sophistication of monetary policy instruments and the discipline of fiscal policy.

Given the highly centralised nature of government and decision making in Jordan (Carol, 2003, p.43), it is not surprising that the CBJ was established with little political independence. In this regard, the governor of the CBJ and his two deputies were, and still, are appointed by the Cabinet subject to the approval of the King for renewable five-year tenures. The remaining five members of the board of the CBJ are also appointed by the Cabinet for renewable three-year tenures. The law stipulates that board members should possess wide experience in economic and banking matters, with one member representing licensed banks

\footnotetext{
${ }^{6}$ This was stated in the speech given by the Jordanian minister of finance at the eighth annual meeting of Middle Eastern and North African bank chief executives in 2005.

${ }^{7}$ Political independence often refers to the capacity of the central bank to choose the final goals of monetary policy, such as inflation or the level of growth, while economic independence as the capacity to choose the instruments with which to pursue these goals. Measurement of political independence often analyses the procedures of hiring and dismissing the central bank's governor and its board, while economic independence measures the ability of the central to operate monetary policy instruments freely, such as setting the interest rate and freedom from budget deficit finance. The literature also distinguishes between goal/target independence and instrument independence. See, for example Grilli, Masciandaro, and Tabellini (1991), Cukierman (1992), and Bofinger (2000).
} 
and specialised credit institutions. Thus all eight board members are appointed by the government without requiring any formal consultation or approval by the governor; this grants the CBJ very little political independence. ${ }^{8}$ The CBJ is also formally accountable to the government and is required to submit a report of its operations along with its balance sheet to the minister of finance within three months of the end of the fiscal year.

The 1971 law states that the statutory objectives of the CBJ are to maintain monetary stability, ensure the convertibility of the JD and promote sustained economic growth according to the general economic policy of the government. The explicit mention of monetary stability grants the CBJ a degree of political independence in implementing monetary policy vis-à-vis the government; yet the same law states that the par value of the JD against gold or foreign currency is determined by the Council of Ministers. Given the fixed exchange rate regime pursued by Jordan, the CBJ has little target or goal independence. The law, however, grants the CBJ a higher degree of instrument independence, as it is free to set its discount rate and upper and lower limits for bank borrowing and lending rates and, in the absence of such limits, to make rules and directives to influence interest rate setting and credit expansion.

The earlier CBJ law of 1966 had limited temporary lending to the government to cover budget deficits of up to 10 percent of the average government revenues for the previous three years and allowed the CBJ to charge interest on such loans. The 1971 law was more lenient and allowed the CBJ to provide interest-free loans of up to 20 percent of government revenues as projected in the budget law for the year in which the advance was granted. In practice, the CBJ's lending to the government has systematically exceeded the 20 percent limit since 1980 according to CBJ data. From 1983 to 1990, average annual CBJ lending to the government was 52 percent of revenues with a peak of 95 percent in $1989 .{ }^{9}$

\footnotetext{
8 This is consistent with Gisolo (2008), where Jordan's central bank independence was ranked relatively low compared with other MENA countries on account of the strong government involvement in the appointment and dismissal of the governor and the board (p. 35).

${ }^{9}$ The on-going financing of the budget deficit was reflected in the return to a questionnaire on central bank independence administered to CBJ staff in early 2004, in which they responded that there was no limit on CBJ lending to the government during the 1980s. Later during interviews, conducted in June 2004, CBJ staff confirmed that the existence of a provision for exceptional loans was interpreted as 'no limits' on lending
} 
As mentioned earlier, monetary policy was generally passive, and accommodated an expansionary fiscal policy in the 1980s; however, the balance of payment crisis and the sharp depreciation of the currency trigged a significant shift in both monetary and fiscal polices. In response to the crisis, starting in late 1988 monetary policy was tightened by raising interest rates and reserve ratios. The CBJ also raised its discount rate from 5.75 percent to 7 percent in September 1988 and again to 8.5 percent in August 1989. To tighten monetary conditions further, the CBJ raised the required reserve ratios on time and savings deposits from 6 to 9 percent and the reserve ratio on demand deposits from 9 to 11 percent in late 1989. The ceiling on bank deposit rates was removed and the ceiling on lending rates charged by commercial banks was increased. As part of the initial stabilisation and reform phase, the interest rate structure was liberalised in February 1990 and as a result the lending rate reached 12 percent by September 1990, up from 10.3 earlier in the year. However, inflation was still high, at 16 percent in 1990, implying negative real interest rates.

Monetary policy was tightened further from 1992 to 1994 as reserve requirements were raised several times (IMF, 1995 pp. 44-46). Both credit to the government and overall domestic credit shrank in 1991 and 1992, while money supply grew by only 3 percent. As a result of tightening monetary conditions and raising interest rates on local currency, the CBJ started to accumulate foreign reserves again and its stock of foreign exchange reserves almost doubled between 1990 and 1993.

The tight monetary policy continued into the late 1990s. Banking sector credit to the government continued to show negative rates of growth into the late 1990s with overall domestic credit growing by an average of 5 percent from 1990-1997, and money supply growing by 6 percent on average over the same period. The CBJ discount rate reached 9 percent by 1998, and commercial banks' lending rates were in the range of 12.5-14 percent, as inflation continued to drop to 3 percent implying real interest rate of about 10 percent (CBJ data).

despite the statutory limitation of 20 percent of revenues. Central bank finance of the deficit is a key element in determining actual CBI, which in the case of Jordan seems to have been low until the early 1990s. 
Fiscal policy improved during the 1990s. CBJ Data shows that in 1992, the fiscal balance registered a surplus of 1.2 percent excluding grants. By 1999, the fiscal deficit was small at 2.4 percent of GDP including grants and 5.8 percent without them, which is a significant improvement from the pre-crisis averages of 7 percent and 15 percent respectively in the 1980s. Total government debt was halved from over 200 percent of GDP in 1989 to 100 percent of GDP by 1999, reflecting the cut in the share of foreign debt by the same magnitude. Together the tightening of monetary policy and the efforts to control the fiscal deficit enabled Jordan to maintain the credibility and durability of the fixed exchange rate and achieve stable low inflation and sustainable growth. The following table summarizes key macroeconomic outcomes.

Table 1: Macroeconomic Developments

\begin{tabular}{lcccccc}
\hline \multicolumn{1}{r}{ Period Average } & 1981-85 & 1986-1990 & 1991-95 & 1996-2000 & 2001-05 & 2006-08 \\
\hline Inflation & 5.4 & 9.7 & 4.3 & 2.8 & 2.4 & 8.9 \\
& & & & & & \\
Real GDP growth & 4.7 & -0.3 & 6.3 & 3.1 & 6.6 & 6.7 \\
\hline Source IFS
\end{tabular}

The change in policy stance was supported by the introduction of indirect control instruments to influence monetary conditions, which increased the ability of the CBJ to conduct monetary policy (see details below). The increased sophistication of the monetary framework and improved design and implementation of monetary policy both impacted and reflected the enhanced status and independence of the CBJ.

In the post crisis environment, the actual independence of the CBJ was enhanced as it had been advising against the risks of chronic fiscal deficits and excessive monetization of the deficit. As the crisis erupted, the authorities felt that heeding the advice of the CBJ would have perhaps reduced the likelihood and/or cost of the crisis.

Although the central bank law itself did not change to reflect the increased actual independence of the CBJ, the legal framework governing its operations was improved significantly with the introduction of the new public debt law in 2001, which instituted ceilings on public debt and tightened the limits on government borrowing from the central 
bank, thus enhancing its actual independence (see details in the coming section). In addition, Article 25 of the central bank law was amended to stipulate that the central bank must be consulted when the Cabinet determines the par value of the currency, which had not been required in the previous laws. Those two amendments to the legal framework improved both target and instrument independence of the CBJ relative to earlier legislation.

In addition, the new law established a committee to manage public debt, in which the CBJ was granted a larger role in the process of debt management. The committee is formed of three members, including the governor of the CBJ, the minister of planning and the minister of finance as chair. The law authorised the minister of finance to borrow on behalf of the government only after the approval of the Committee. Also, Article 11 of the new law states clearly that the minister of finance shall decide on the annual plan for issues of public debt and determine the terms of issue upon consultation with the Governor.

Some insight into the degree of independence of the CBJ during the 1990s can be found in the Bank of England survey on monetary frameworks, published in 2000. The survey catalogues key aspects of the monetary framework in a sample of 94 countries around the world, using survey results obtained directly from individual central banks. The survey included questions in several categories, including: the statutory objectives of monetary policy; the ability to use monetary policy instruments; the legal framework governing the appointment of the governor and the board; and operational aspects of monetary policy setting. An aggregated score for overall independence was then derived from the individual categories. The overall assessment of central bank independence, thus, incorporated elements of both legal and actual independence. On overall instrument and target independence indicators, the CBJ attained the full score of 100, reflecting a high degree of actual independence despite the low scores (50 out of 100) awarded to the individual indicators pertaining to the statutory objective of price stability and budget deficit finance. However, this particular aspect of budget deficit finance improved significantly in 2001 with the adoption of the new public debt law. The composite index score, reflecting the overall independence of the CBJ was 75 out of 100, which compares well with other MENA countries included in the survey and is above the developing and emerging market countries' average. 
Table 2: Bank of England CBI index - Jordan and select MENA countries

\begin{tabular}{l|c}
\hline & $\begin{array}{c}\text { Bank of England CBI Index } \\
\text { Score (max. 100) }\end{array}$ \\
\hline Egypt & 53 \\
Jordon & 74 \\
Lebanon & 68 \\
Turkey & 70 \\
Emerging Market & \\
Average & 65 \\
\hline
\end{tabular}

A more recent study by Gisolo (2008) analyzed central bank independence in a number of MENA and Southern Mediterranean countries, including Jordan. ${ }^{10}$ The study adopts a methodology the focused on quantifying central bank independence by focusing on legal independence as specified in the various central bank laws, rather than measures of actual independence. The research assessed legal independence on various dimensions, including: policy objectives and the emphasis on price stability, policy formulation, political independence, economic independence, and accountability. Each central bank in the sample was assigned a score in each of the above categories, based on sub-indicators, before arriving at an aggregated score for overall independence. Unlike many other studies that quantify central bank independence, Gisolo’s indicators included the possibility of assigning negative values on most indicators.

In Gisolo's ranking, the CBJ was found to be among the least independent central banks with an overall score of -0.25 , relative to an average score of 1.92 , and a maximum score of 4.25 (Algeria).

Gisolo’s overall assessment of CBJ's independence is driven by the low (and negative) scores assigned to the CBJ's political independence. As the paper indicated (p. 35), the overall ranking is largely driven by the provisions for the hiring and dismissal of the governor and the board. This seems to overwhelm the high (sometimes full) scores assigned

\footnotetext{
${ }^{10}$ Gisolo (2008) studied a sample of MENA countries, including: Algeria, Cyprus, Egypt, Israel, Jordan, Lebanon, Libya, Malta, Morocco, Palestine, Tunisia, and Turkey.
} 
to economic and instrument independence; particularly the freedom from budget deficit finance, where the CBJ is awarded the full score; consistent with more recent developments. Therefore, ranking the CBJ among the least independent in the MENA region appears to be biased downwards, given the critical importance of instrument independence - including limits on lending to the government - in determining actual independence, as several studies have shown (Cukierman,1992; Fry, 1998; and Mahadeva and Sterne; 2000).

In sum, the monetary framework witnessed clear positive developments since the early 1990s, in that the CBJ is now enjoying a higher degree of actual independence. Although the central bank law itself did not change, the overall legal framework, which governs central bank operations, has improved with the 2001 public debt law, which prohibited direct lending to the government. This represents a significant improvement over previous legislation.

\section{MONETARY POLICY INSTRUMENTS AND OPERATIONS}

The main change in the operation of monetary policy in Jordan was the adoption of indirect control instruments, in the early 1990s which improved the ability of the CBJ to conduct monetary policy and supported its increased autonomy.

In September 1993, the CBJ introduced an auction system for its own certificates of deposits (CDs). Initially, the CBJ was using M2 as an intermediate target to achieve its final objective of maintaining price stability and the exchange rate peg. The CBJ aimed at maintaining bank reserves at the required minimum level at all times (IMF, 1995). By mid-1995, the CBJ had expanded the use of CDs to implement monetary policy and shifted to using the CD auction rate as its operational target. At the same time, the CBJ intervenes in the foreign exchange market to maintain the exchange rate peg. By targeting the $\mathrm{CD}$ rate, the $\mathrm{CBJ}$ tried to influence bank lending and deposit rates so as to induce changes in demand for the JD relative to the USD and maintain exchange rate stability. Thus after 1995, the intermediate target of monetary policy changed from M2 to the banking system interest rates

The CBJ influences the CD interest rates by varying its offerings of CDs at auction, and this would directly impact retail interest rates in the banking system (Poddar et. al, 2006); 
however, in recent years, banking sector interest rates have been less responsive to CBJ policy rates.

The 3-month CD interest rate was maintained at between 9 and 9.55 percent from 1995 to 1998 to coincide with the tight monetary policy pursued by the CBJ throughout the 1990s. The CBJ used its CDs as the main instrument to control the money supply and absorb excess liquidity. A decade of tight monetary policy resulted in a reduction of inflation to very low levels: by 1999 inflation stood at 1 percent after averaging 4 percent between 1991 and 1999, while real GDP growth was 5 percent on average over the same period.

The change in the CBJ's policy framework from targeting M2 to targeting interest rates coincided with the change in the nature of the exchange rate peg from pegging the JD to SDR within a narrow margin to fixing it completely to the USD where the JD remained unchanged against the USD at the rate JD 0.71/USD until now.

In 1998, the CBJ introduced another instrument to its indirect instruments kit: it launched an overnight deposit facility, which gave the CBJ a tool for managing liquidity on a daily basis and provided a floor for inter-bank rates. In 2000, the CBJ started adjusting the overnight rate in line with the changes in the US Federal funds rate. Thus since 2000, the CBJ has moved away from solely targeting $\mathrm{CD}$ auction rates to a corridor system with the overnight window as the floor and the 7-day repo facility, which had been introduced in 1994, as the ceiling (Poddar et. al, 2006; p. 7). In May 2007, the CBJ simplified its interest rate structure, by reducing the interest rate corridor width by 125 basis points, as it replaced the seven-day repo facility with an overnight facility to ensure symmetry with the overnight deposit window.

Poddar (2006) argued that the CBJ still had some independence in setting the interest rate spreads between the level of domestic interest rates and that in the US due to imperfect asset substitutability. Further empirical analysis also supports this conclusion as will be discussed in section V. The following graph shows the evolution of the central bank's CD rate since 1999, relative to that of the Federal Funds' rate. The CBJ policy rate remained stable at 6 percent in 2000 and fell to 3.9 in 2001 despite the increase in the federal fund's rate of 1.27 percentage points. Recently, the decoupling of the CD rate from the US federal funds rate became more pronounced, as the CBJ kept interest rates considerably higher than in the US due to its concern over inflationary pressures emanating from the pass-through of food and 
fuel price shocks in 2007 and early 2008, and to avoid pressure on the balance of payment after the breakout of the global financial crisis in late 2008 (IMF, country report 2008; 2009).

Chart 1: CD Rate and Fed. Funds Rate

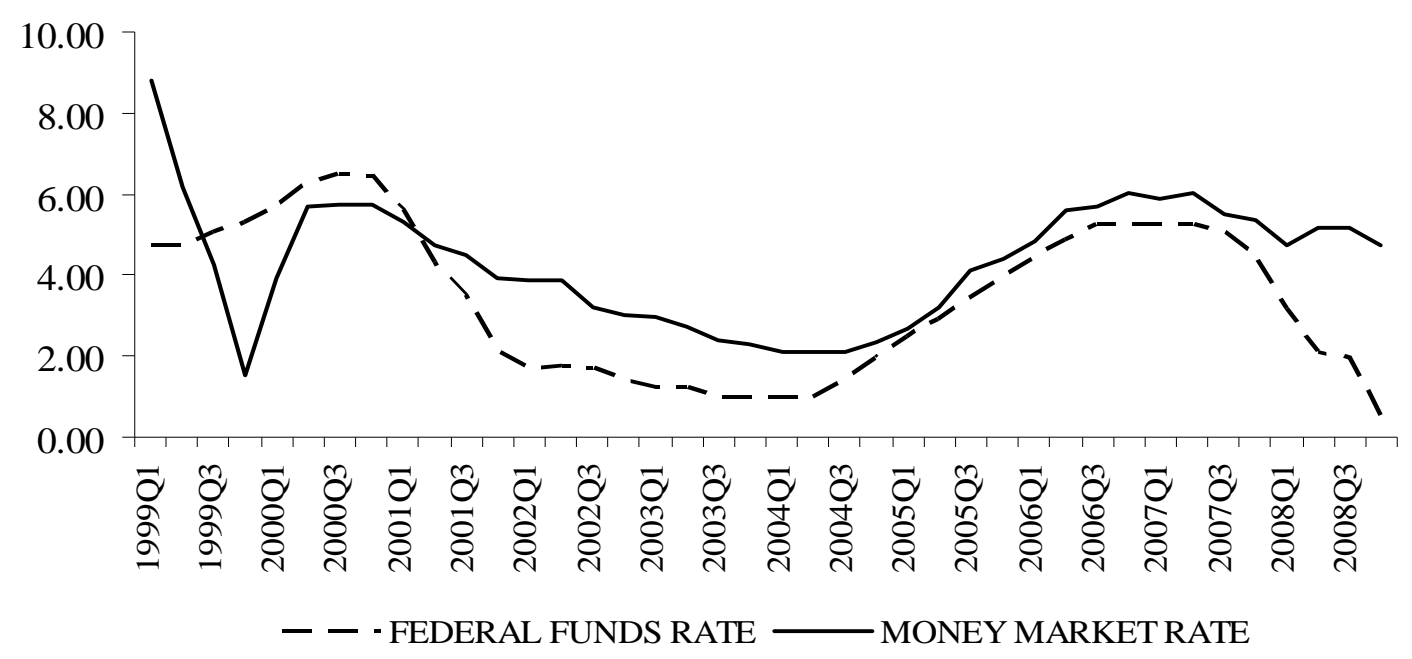

Since 2000, the main features of the monetary framework remained broadly unchanged. Two main developments since then are important to mention: the monetary stance of the CBJ became more accommodating in the early 2000s, and the government enacted a new public debt law, which introduced ceilings on foreign and domestic public debt, and tightened the limits on government borrowing from the central bank, which enhanced its actual independence.

In 1999, the average 3-months CD rate was reduced to 6 percent from 9.5 percent in 1998 and it continued to decline, reaching 2.9 percent in 2004. The discount rate followed the same pattern and stood at 3.8 percent in 2004, down from 9 percent in 1998. Similarly, banking sector interest rates showed a falling trend after 1999. Starting in 2005, the CBJ reversed the declining trend in interest rates due to concerns over high credit growth, and the emergence of inflationary pressures in 2006 (IMF, country report 2007).

Kanakria (2002) attributed the change in the stance of monetary policy to the unprecedented level of foreign reserves at the CBJ, reaching seven months of imports at the end of 1999. 
This signalled the confidence in the JD and allowed the CBJ to lower interest rates on CDs, which fed into banks' interest rates.

Compared with the monetary framework, the area of public finance witnessed more significant changes since 1999, as the government enacted a new public debt law and replaced direct borrowing from the banking system, including the CBJ, with issuance of Treasury bills to finance its deficit.

A new law for public debt management was passed in 2001 and was later complemented by a Memorandum of Understanding (MoU) between the CBJ and the Ministry of Finance in March 2008. The 2001 law prohibited the government from direct domestic borrowing from commercial banks or any other institutions and limited domestic borrowing to the issuing of securities, while the more recent MoU eliminated the interest-free overdraft facility at the CBJ, which had funded the government short-term cash needs.

The public debt law also deals with the government's debt to the CBJ by freezing it at the stock outstanding in April 2001 at the time when the new law entered into force. The 2008 MoU set a clear strategy for the settlement of the overdrawn balance, by securitizing the debt and sharing the government's borrowing plans with the CBJ on a quarterly basis to help coordinate liquidity management.

In addition Articles 21-23 of the law limit the stock of both foreign and domestic debt at any point in time to 60 percent of GDP each and the total outstanding public debt to 80 percent of GDP at current prices of the latest year for which data is available. The public debt ceiling stated in the 2001 law is expected to be reached by 2011 through fiscal adjustment and the introduction of new debt instrument, as well as improving the capacity of public debt management (IMF country report, 2008).

The government started holding regular TB auctions in the fall of 1999 and the stock of government securities (bills and bonds) grew from JD 330 million in 1999 to JD 1500 million in 2004, and it reached 4133 million by October 2008 (CBJ data). As such, government issuance of bills and bonds represents 62 percent of the total stock of domestic debt outstanding, amounting to JD 5.3bn (\$7.5bn), while CDs issued by the CBJ account for 32 percent and the remainder is made up of corporate securities (4 percent), bonds issued by public entities ( 2 percent) and development bonds (less than 1 percent). 
In 2008, treasury bonds accounted for most of the government's domestic debt (about 80 percent), while T-bills constitute the rest. T-bonds are currently issued at 3- and 5-year maturities. The average remaining maturity on the current stock of T-bonds is roughly 2 years, and it carried a weighted average yield of 7.4 percent. T-bills are currently issued at a 1-year maturity, while CDs are issued at 3- and 6-month maturities, typically on a bi-weekly basis. Banks are the primary holders of domestic debt issued by the government, as they hold about 94 percent of the T-bill market and 65 percent of the T-bond market with the rest held by the Social Security Corporation (SSC), which takes up 4 percent and 28 percent of the respective totals. A much smaller percentage of these markets are held by corporate savings plans.

There is strong demand for government securities from the banking sector, as they offer relatively high returns; short-term T-bills offered over 100 basis points more than the deposit window rate at the central bank in early 2008. Rates on government securities are typically higher than CDs as well. In the absence of other alternative investments, commercial banks tend to hold government securities to maturity. Public debt securities are issued using a multiple (or discriminatory) price auction. Banks, the SSC and other financial companies (including insurance companies) are eligible to bid directly in the auction; other investors must channel their bids through a bank.

Since early 2000s, the structure of public debt has increasingly moved from external to domestic debt, where the share of foreign currency debt has fallen from over 80 percent of total debt in 2001 to below 50 percent in 2008. This development considerably reduced the vulnerability to external shocks and exchange rate pressures. Historically, the government had relied on concessional foreign debt and borrowing from the CB to finance the budget deficit. The government believed that domestic borrowing through T-bills was too costly compared with the other sources of finance. However, as the government borrowed abroad, the CBJ was forced to use CDs to sterilize the impact of government borrowing on domestic liquidity, with additional interest cost. The total cost of borrowing, if one considers both the direct cost of borrowing abroad and the cost of sterilization using CDs, would be lowered if the government used T-bills to borrow directly from the banking system. Initially, the government had been reluctant to do so because the cost of CDs does not appear directly in 
its balance sheets and is born entirely by the CBJ. In practice, however, sterilization costs reduce CBJ profits and comprise the strength of its balance sheet.

In 2002, the CBJ started to reduce the stock of CDs on offer to contain the cost of sterilization, as it had been making losses as a result of issuing CDs. However, the impact of this policy was to direct the excess liquidity still available in the banking system to the overnight deposit window almost at the same interest rate. This policy may also have been more costly to the CBJ, as the very liquid nature of overnight deposits allowed commercial banks to reduce the level of frictional balances that it might have kept otherwise. In response, the CBJ implemented an alternative policy of reducing both the volume of CDs and the overnight interest rate, which sets the floor for the CD rate determined by auction. This contributed to channelling excess liquidity back to CDs at a lower cost to the CBJ.

In contrast with the mostly subservient nature of the relation between the CBJ and the government during the 1980s, the evolution of the monetary framework and the increased

discipline of fiscal policy necessitate greater coordination between the government and the central bank. This issue became particularly important with the elimination of the government's overdraft facility at the CBJ, as the government starts to increase its reliance on short-term T-bills to replace the eliminated overdraft facility.

In the medium term, it may be more efficient to replace the CBJ CDs with government Tbills as a tool for monetary management. As the government introduces a short-term T-bill (perhaps 3-months bills), the CBJ could use it to conduct open-market operations; however this would require close coordination between the CBJ and the Ministry of Finance. This would reduce the combined cost of borrowing and sterilization, and would contribute to the development of a secondary bond market.

\section{Monetary POLicy AUTONOMY}

Recent literature has documented that operating a flexible exchange rate is not the enabling factor in implementing an independent monetary policy, as countries operating a flexible exchange rate regime were equally (if not more) responsive to world interest rates as those operating a fixed regime (Frankel, 1999; Frankel et al. , 2002; Fratzscher, 2002). Monetary 
independence, or lack thereof, is determined by the influence of world interest rates on domestic interest rates. Jordan has operated a fixed exchange rate to the USD since 1995, which has been successful in providing a credible anchor for monetary policy. The exchange rate peg has served Jordan well in maintaining price stability and attracting foreign capital and investment, particularly from the region. This section will examine whether Jordan is also able to maintain a degree of autonomy in operating monetary policy, given its fixed exchange rate peg.

The literature has proceeded on the assumption that monetary independence should allow countries to avoid responding to world interest rates, and any influence from foreign interest rates has been taken as an indicator of the loss of independence of the domestic monetary policy. The current work; however, employs a more nuanced definition of monetary independence. World interest rates cannot be ignored as an important determinant in the design of monetary policy in emerging markets and ignoring it will be misleading; the definition of monetary independence applied here, and put forward in earlier work, ${ }^{11}$ accepts the fact that as emerging markets integrate further into the global economy, the impact of world interest rates is going to increase. However, this natural phenomenon does not necessarily preclude the operation of a monetary policy that is geared towards achieving domestic objectives. In a sense, the point is not whether developing countries are responding to world interest rates, but whether they are still able to respond to domestic objectives at the same time.

To analyze the response of monetary policy in Jordan to US interest rates and domestic conditions, cointegration analysis and a Vector Error Correction Model (VECM) were estimated using quarterly data from 1999 to 2008. The objective of this analysis is to investigate the degree of monetary policy autonomy in Jordan, as defined above.

The domestic variables used to assess monetary independence are the inflation differential and the output gap differential between Jordan and the US. The output gap differential was

\footnotetext{
${ }^{11}$ This definition of monetary policy independence was put forward in earlier empirical work that did not include Jordan (Maziad, 2008).
} 
constructed using quarterly GDP data. The output gap was calculated by regressing GDP on a linear and quadratic trend function and the output gap was obtained as the residuals of this regression. The output gap series was standardized by dividing the quarterly observations by the series' own standard deviation. The standardized differential output gap between the domestic economy and the US economy is the variable used in the analysis to assess the response of monetary policy to the real economy. The reason for this procedure is that output gaps in emerging market countries are typically larger in both directions compared with those in developed countries such as the US; the standardization process of the output gap series makes it possible to capture the relationship between the two business cycles which could have been masked by the larger magnitude of variation in Jordan had the series not been scaled using the standard deviations.

Using Johansen cointegration technique, a long-run relationship was found between the variables in the system. ${ }^{12}$ A Cointegrating relation exists between domestic interest rate $(r)$, US interest rate $\left(r^{*}\right)$, inflation differential $(\pi)$, and the output gap differential $(y)$, of the following form (T-stats are provided between brackets):

$$
r=1.39+\underset{(26.9)}{0.74} r^{*}+\underset{(17.8)}{0.83} \pi+\underset{(9.1)}{0.77} y
$$

As expected, the policy rate in Jordan responds to changes in the US interest rate. At the same time, monetary policy also reacts to domestic variables; inflation and the output gap differentials. Given the definition of monetary policy independence put forward, the CBJ has some autonomy in designing monetary policy in response to domestic variables. Essentially, the results point to the latitude that the CBJ has in setting the interest rate spread between the JD and the USD. An alternative specification of the model, using explicitly the interest rate

\footnotetext{
${ }^{12}$ The standard Augmented Dickey-Fuller tests was run to test for the order of integration, the null hypothesis of unit root could not be rejected for both interest rate series and could only be rejected at the 5-10 percent level for the inflation and output gap differentials.
} 
spread confirmed the results, showing that the domestic variables influence the interest rate spread with broadly similar long-run coefficients. ${ }^{13}$

A VECM model was estimated to distinguish the short-run responses of monetary policy to the different variables and identify the speed of adjustment to the long-run equilibrium. A VECM is a restricted VAR designed for use with nonstationary series that are known to be cointegrated. The VECM has cointegration relations built into the specification so that it restricts the long-run behavior of the endogenous variables to converge to their cointegrating relationships while allowing for short-run adjustment dynamics. The cointegration term is known as the error correction term since the deviation from long-run equilibrium is corrected gradually through a series of partial short-run adjustments. The estimated VECM was of the following form, where the lag length was identified using the Akaike criteria.

$$
\Delta r_{t}=\sum_{p=1}^{P} D_{p} \Delta r_{t-p}+\sum_{k=0}^{Q} B_{k} \Delta r_{t-k}^{*}+\sum_{l=0}^{L} G_{l}{ }^{\prime} \Delta X_{t-l}-\delta\left[r_{t-l}-c-\beta r_{t-1}^{*}-\gamma^{\prime} X_{t-1}\right]+u_{t}
$$

where $r_{t}$ is domestic interest rate (r_jor), $r_{t}^{*}$ is US interest rate (r_US), $X$ is a vector of exogenous variables, including inflation $(\pi)$ and the output gap differential $(y)$ as discussed above, $u$ is an error term, and $\delta$ is the speed of adjustment to the long-run equilibrium. Table 1 in the appendix provides the detailed results from the VECM estimation.

Short run dynamics indicate that domestic interest rate adjusts relatively fast to the long-run equilibrium, where the speed of adjustment $(\delta)$ was estimated at 0.5 . The coefficients on most of the lagged variables were statistically insignificant, except for those on the first lag of the inflation differential and out gap differential, which were statistically significant at the 5 percent level.

The results of the VAR/VECM analysis were used to obtain the impulse response functions and the variance decomposition of the response of the domestic policy rate to the different variables in the system over a forecast horizon of 10 quarters. The results of the impulse

\footnotetext{
${ }^{13}$ The cointegration analysis was run on an alternative specification, using the interest rate spread, the inflation differential, and the output gap differential. The results were broadly similar to those presented in the paper.
} 
response functions show that the domestic policy rate responds gradually to innovations in US interest rates until it peaks at about 7 quarters, after which the impact fades, while the response to the inflation differential is initially stronger, peaking at the fourth quarter. Based on the VAR analysis, the policy reaction to the output gap differential seems small (see Appendix, Fig. 1).

Variance decomposition results show the share of fluctuation in the domestic policy rate that can be attributed to individual shocks (or variables in the system). Table 2 in the Appendix provides the variance decomposition results obtained from the VECM analysis, where the columns provide the percentage of the variation due to each shock, while the rows add up to 100 percent in each period. The results suggest that in the second quarter, innovations to the US interest rates can explain about 3.5 percent of the variance in the domestic interest rate, reaching a peak of 57 percent after 8 quarters. On the other hand, domestic variables, inflation and output gap differentials combined; explain about 17 percent of the variation in domestic interest rates by the fourth quarter. Variance decomposition results confirm the VAR impulse response analysis, where the impact of the output gap differential is small, especially compared to the policy response to the inflation differential.

Compared with other emerging markets operating a fixed exchange rate regime, the impact of the US interest rate appears moderate, while the speed of adjustment is relatively high. Frankel et. al (2002) analyzed the degree of monetary policy independence in a sample of 46 industrial and developing countries. They applied OLS with fixed effects to panel data and controlled for periods of transition and currency crisis distinguishing between different exchange rate regimes, and distinguishing different time periods. Their results indicated that during the 1990s, on average the long-run coefficients on the US interest rate were 1.81 for fixed regimes, 0.81 for intermediate regimes and 0.91 for freely floating regimes.

In a sample of 19 emerging markets spanning the period from 1990 to 2005, the same type of analysis was conducted using OLS estimation of single-equation ECM on individual countryexchange rate episode, distinguishing between fixed and flexible exchange rate regimes. In that analysis, the long-run coefficient on the US interest rate was statistically significant in almost all the cases and averaged 1.5 for fixed exchange rate episodes, while the speed of adjustment for that group averaged 0.3 (Maziad, 2008). 
As such, the results indicate that the influence of US interest rates on policy in Jordan is smaller than in other emerging market markets operating a fixed exchange rate, while monetary policy in Jordan is also responsive to domestic inflation and the output gap differential. One caveat is to note the ability of a country like Jordan to deviate from US interest rates by maintaining interest rates above those in the US, while deviations in the opposite direction maybe difficult. In other words, monetary policy independence, as such, could be asymmetric. Over the study period, the output gaps in the US and in Jordan were positively correlated with a correlation coefficient of 25 (t-statistic 1.55), ${ }^{14}$ which may have facilitated following the US monetary policy without sacrificing domestic policy objectives; in addition, concerns over inflationary pressures in Jordan led the CBJ to widen the margin between the interest rates in the two countries, which implied policy independence in the analysis. While it would be still possible to narrow the interest rate margin, as the CBJ did during the period from 2002 to the end of 2005 (see chart 1), it might not be feasible, in the context of a fixed exchange rate, to loosen monetary policy to the point where interest rates are below those in the US due to concerns over inflationary expectations, potential loss of reserves, and the credibility of the peg.

\footnotetext{
${ }^{14}$ A seasonally adjusted output gap series for Jordan showed a correlation coefficient of 0.67 (t-static: 5.54).
} 


\section{Conclusion}

The paper examined central bank independence and monetary policy operations in Jordan, as well as the issue of monetary autonomy in the context of Jordan's exchange rate peg. The Jordanian monetary framework has evolved considerably since the balance of payments crisis, where the domestic currency lost more than half of its value in 1988-89. In the aftermath of the crisis, the authorities embarked on a process of monetary and fiscal reforms, which restored confidence in the currency and assisted in the maintenance of a fixed exchange rate regime for over a decade and a half. In addition, over the past eighteen years, the CBJ has gradually developed a higher degree of central bank independence such as it had not enjoyed early in its history.

The legal and actual independence of the CBJ increased and its ability to achieve monetary stability improved with the adoption of more sophisticated indirect control policy instruments. At the same time, the government is working towards greater fiscal consolidation and improving its debt management abilities. This development along with the CBJ's acquired skills and experience in managing monetary policy enhanced its actual independence, thus emphasizing the need for better coordination between fiscal and monetary policies.

The empirical analysis presented in the paper points to the ability of the CBJ to shape monetary policy in response to domestic policy objectives, even in the presence of a strong influence from US interest rates. The VAR/VECM results suggest that the CBJ responds gradually to changes in US interest rates over a period of about 8 quarters, while also accommodating domestic variables: the domestic inflation and the output gap differentials between Jordan and the US. After an extended period of successfully operating a fixed exchange rate regime, the $\mathrm{CBJ}$ has built a credible track-record of maintaining low and stable inflation without restricting economic growth. With that experience, the CBJ could be able to make the transition to a more flexible monetary policy framework in the medium-term, if the authorities wish to do so, such as an inflation targeting framework that could grant it more independence in operating monetary policy. 


\section{APPENDIX}

Chart 1: VAR estimation impuls response function

Response to Cholesky One S.D. Innovations \pm 2 S.E.
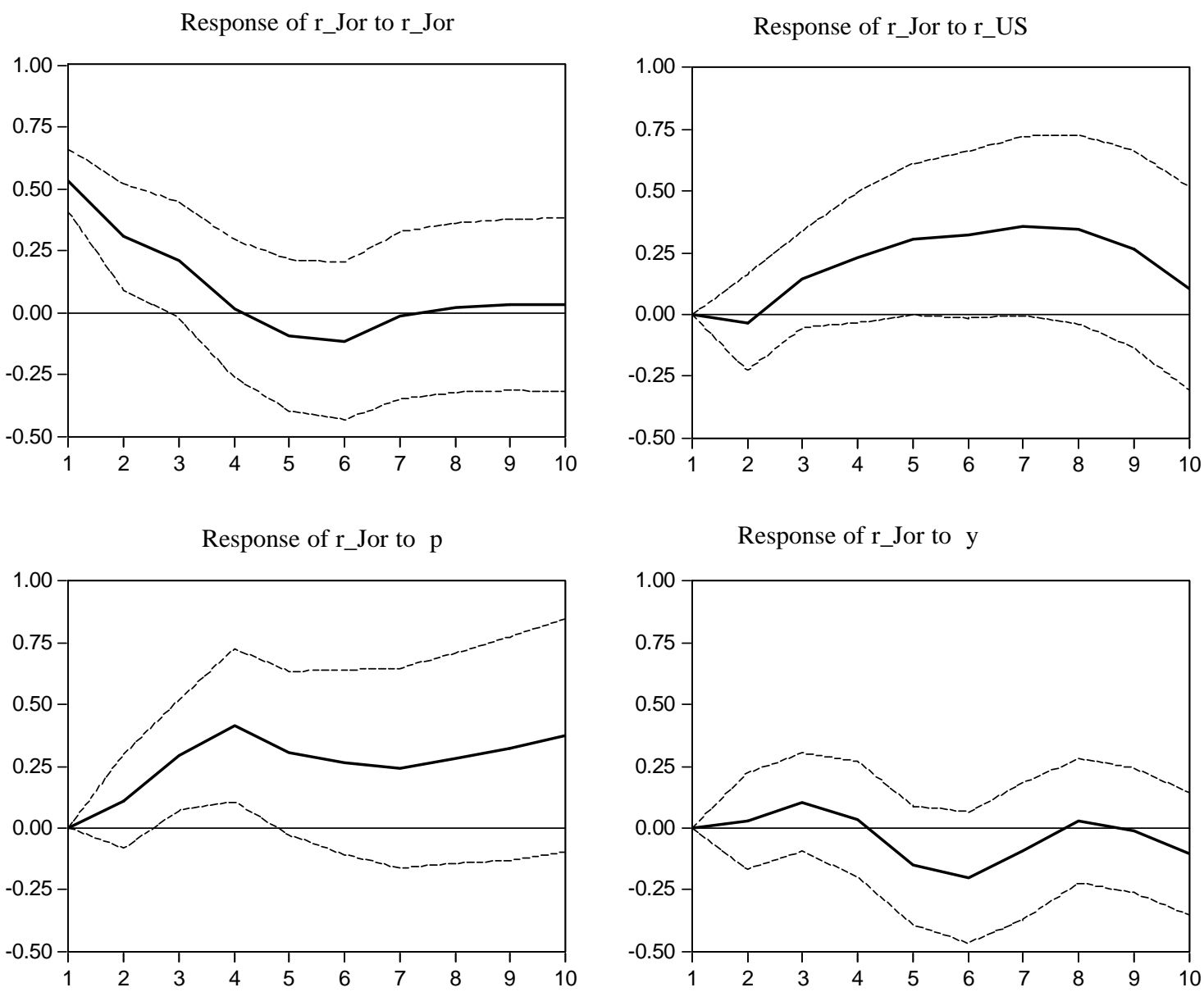


\section{Table 1: VECM estimation}

Vector Error Correction Estimates -T stats in []

Cointegrating Equation:

r_Jor(-1)

r_US(-1)

$-0.736006$

$\pi(-1)$

[-26.8556]

$-0.834533$

[-17.8792]

y $(-1)$

$-0.766947$

[-9.07574]

C

$-1.399098$

Error Correction:

Error correction term

$-0.498103$

[-2.08138]

D(r_JOR(-1))

0.114278

[ 0.69715]

D(r_JOR(-2))

$-0.05902$

[-0.40443]

D(r_JOR(-3))

$-0.08108$

[-0.65818]

D(r_US(-1))

$-0.089543$

[-0.25957]

D(r_US(-2))

0.241891

[ 0.75967]

D(r_US(-3))

0.384351

[ 1.48891$]$

$\mathrm{D}(\pi(-1))$

$-0.339432$

[-2.01728]

$\mathrm{D}(\pi(-2))$

$-0.129941$

[-0.85263]

$\mathrm{D}(\pi(-3))$

$-0.031617$

[-0.34991]

$\mathrm{D}(\mathrm{y}(-1))$

$-0.30641$

[-2.06503]

$\mathrm{D}(\mathrm{y}(-2))$

$-0.159538$

[-1.44195]

$\mathrm{D}(\mathrm{y}(-3))$

$-0.123202$

[-1.65448]

C

0.128831

[ 1.88310$]$

R-squared

0.779269

Adj. R-squared

0.642626

Sum sq. resids

2.945599

F-statistic

5.702961

Log likelihood

$-6.34972$ 
Table 2: VECM variance decomposition of policy rate in Jordan

\begin{tabular}{cccccc}
\hline Period & S.E. & r_Jor & r_US & $\pi$ & $y$ \\
\hline 1 & 0.37 & 100.00 & 0.00 & 0.00 & 0.00 \\
2 & 0.48 & 94.65 & 3.46 & 1.39 & 0.50 \\
3 & 0.65 & 64.49 & 21.10 & 12.22 & 2.20 \\
4 & 0.90 & 43.17 & 38.17 & 16.98 & 1.68 \\
5 & 1.12 & 33.34 & 47.34 & 17.66 & 1.67 \\
6 & 1.32 & 27.31 & 52.74 & 18.36 & 1.60 \\
7 & 1.54 & 23.11 & 56.04 & 18.67 & 2.17 \\
8 & 1.75 & 19.88 & 57.12 & 20.65 & 2.35 \\
9 & 1.94 & 18.07 & 57.09 & 22.52 & 2.32 \\
10 & 2.09 & 16.83 & 56.77 & 24.31 & 2.08 \\
\hline
\end{tabular}

Cholesky Ordering: r_Jor, r_US, $\pi$, y 


\section{References}

Abu-Hammour, Mohamed (2005). Jordan’s Economic Reform (speech), Eighth Annual Meeting of Middle Eastern and North African Bank Chief Executives, February, Abu Dhabi

Bofinger, Peter (2001). Monetary Policy: Goals, Institutions, Strategies, and Instruments, Oxford University Press.

Brynen, Rex (1992). 'Economic Crisis and Post-Rentier Democratization in the Arab World', Canadian Journal of Political Science, March 1992, pp. 69-97.

Carroll, Katherine (2003). Business as Usual? Economic Reform in Jordan, Lexington

Books.

Cukierman, A. (1992). Central Bank Strategy, Credibility and Autonomy, Cambridge, Massachusetts: MIT Press

Gisolo, E. (2008). 'The degree of legal central bank independence in MENA countries' in Cobham and Dibeh (ed.) Monetary Policy and Central Banking in the Middle East and North Africa, Routledge.

Grilli, V., D. Masciandaro and G. Tabellini (1991). "Political and Monetary Institutions and Public Financial Policies in the Industrial Countries,” Economic Policy, Vol. 13, pp. 341-92

International Monetary Fund (1995). Jordan - Background Information on Selected Aspects of Adjustment and Growth Strategy, IMF Staff Country Report No. 95/97

International Monetary Fund (2002). Article IV Consultation with Jordan Public Information Notice, IMF Public Information Notice No. 02/51

International Monetary Fund (2004). Article IV Consultation and Second Review under the Stand-By Agreement - Staff Report, IMF Country Report No. 04/122, May

International Monetary Fund (2005). Jordan: Fifth Post-Program Monitoring Discussions Staff Report, IMF Country Report No. 05/100, March

International Monetary Fund (2007). Jordan: Post-Program Monitoring Discussions - Staff Report, IMF Country Report No. 07/284

International Monetary Fund (2008). Article IV Consultation, IMF Country Report No. $08 / 291$

International Monetary Fund (2009). Article IV Consultation, IMF Country Report No. $09 / 159$

Kanakria, Ezz el-Din (2002). Economic Reform Programs in Jordan and its Impact on Public Finance, Arab University of Jordan, Unpublished papar (Arabic).

Maziad, Samar (2008). Monetary Frameworks in Emerging Market Countries: Exchange Rate Arrangements and Central Bank Independence, Ph.D. Dissertation, School of Economics and Finance, University of St. Andrews, Scotland, UK

Poddar, Tushar, Sab, Randa and Khachatryan, Hasmik (2006). The Monetary Transmission Mechanism in Jordan, IMF Working Paper No. 06/48

Public Debt Management Law No. (26) of 2001, Jordanian Ministry of Finance 
Satloff, Robert (1992). 'Jordan’s Great Gamble: Economic Crisis and Political Reform’ in Barkey, Henri J. (ed.) The Politics of Economic Reform in the Middle East, St. Marin's Press, New York. 